Original Research Paper

\title{
Problematika Pemanfaatan Media Pembelajaran IPA di Sekolah Dasar
}

\author{
Yuliana Wahyu $^{1 *}$, Ambros Leonangung Edu' ${ }^{1}$, Mikael Nardi ${ }^{1}$ \\ ${ }^{1}$ Program Studi PGSD Unika Santu Paulus Ruteng, Flores, Indonesia
}

DOI: $10.29303 /$ jppipa.v6i1.344

Citation: Wahyu, Y., Edu, A., \& Nardi, M. (2020). Problematika Pemanfaatan Media Pembelajaran IPA di Sekolah Dasar. Jurnal Penelitian Pendidikan IPA, 6(1). pp. 107-112

\section{Article history}

Received: November $19^{\text {th }} 2019$

Revised: January $1^{\text {th }} 2020$

Accepted: January $29^{\text {th }} 2020$

*Corresponding Author: Yuliana Wahyu; Program Studi PGSD Unika Santu Paulus Ruteng, Flores, NTT, Indonesia Email: yulianawahyu76@gmail.com

\begin{abstract}
This study aims to describe the availability and use of science learning media in class $6^{\text {th }}$ of Catholic private elementary schools at Langke Rembong District. This research method is in the form of a survey that focuses on two things, namely the availability and use of science learning media. The study was conducted to all the science teachers in class $6^{\text {th }}$ totaling 46 teachers as a population, then the data were only taken from 23 teachers as a sample selected purposively. Instruments used were questionnaires, checklists, interviews, and documentation. The results showed that the availability of science learning media in those schools were sufficient. However, many media were in damaged conditions. Those happened because they were stored, not used. Most teachers were not trained to use that media and had no initiative to solve the problem. Therefore, in terms of utilization, only good media is utilized to its full potential.
\end{abstract}

Keywords: Problematics; Science learning media, elementary school

\begin{abstract}
Penelitian ini bertujuan untuk mendeskripsikan ketersediaan dan pemanfaatan media pembelajaran IPA di kelas VI sekolah dasar swasta Katolik se-Kecamatan Langke Rembong. Penelitian ini berbentuk survei dengan terfokus pada dua hal, yakni ketersediaan dan pemanfaatan media IPA. Penelitian dilakukan terhadap seluruh guru IPA kelas VI berjumlah 46 orang sebagai populasi, selanjutnya data-data penelitian hanya diambil dari 23 orang sebagai sampel yang dipilih secara purposive. Instrumen penelitian berupa kuesioner, check list, wawancara dan dokumentasi. Hasil penelitian mengungkapkan bahwa ketersediaan media pembelajaran IPA di sekolah-sekolah riset sudah memadai. Akan tetapi, banyak media sudah berada dalam kondisi rusak. Kerusakan terjadi karena disimpan, bukan karena digunakan. Media-media lebih banyak disimpan karena ternyata kebanyakan guru tidak diberi pelatihan dan kurang berinisiatif untuk memecahkan masalah tersebut. Karena itu, dari sisi pemanfaatan, hanya media yang baik saja yang dimanfaatkan secara maksimal.
\end{abstract}

Kata Kunci: Problematika; Media pembelajaran IPA, Sekolah Dasar

\section{Pendahuluan}

Proses pembelajaran di kelas dasar memerlukan sarana dan prasarana pendukung, salah satunya media pembelajaran. Penggunaan media diharapkan dapat meningkatnya hasil belajar yang maksimal (Taufiq, 2014: 140). Intervensi media, jika diikuti dengan metode yang tepat, bermanfaat bagi kompetensi siswa dan interaksi pembelajaran serta berpengaruh terhadap cara siswa memproses informasi dari guru. Dalam konteks pembelajaran, tempat media memang hanyalah sebatas penunjang. Media bukan tujuan tetapi sekadar "instrumen atau media berkomunikasi" ( $a$ channel of communication) antara guru dan siswa untuk mencapai tujuan pembelajaran. Meskipun demikian, fakta menunjukkan bahwa tanpa media, pembelajaran menjadi tidak berkualitas. Bandingkan dengan pembelajaran konvensional. Segala sesuatu bercorak verbalistik. Prosesnya monoton. Hanya guru yang berbicara, sedangkan siswa dominan mencatat, mengingat, dan menulis ingatannya saat ujian untuk 
mencocokkan hafalannya agar disebut sebagai siswa yang "cerdas".

Jika proses pembelajaran memanfaatkan media, ada banyak kontribusi positif, di antaranya menghemat waktu dalam penjelasan, meningkatkan minat belajar, menarik perhatian, menjernihkan ide, memperjelas konsep, dan memperkuat ingatan siswa (Naz \& Akbar, 2008: 36). Selain itu, media pembelajaran menjadi sarana penyampaian informasi tentang konsep pembelajaran yang diterima dengan sangat baik (Sari \& Setiawan, 2018:101). Pemanfaatan media sebenarnya diciptakan untuk menghindari verbalisme, membebaskan siswa dari tirani dan tren diobjektifikasi oleh guru, serta membuka selubung persepsi guru yang dominatif-eksploitatif. Banyak riset membuktikan bahwa pemanfaatan media mengubah paradigma pembelajaran, dalam arti status siswa dari objek kepada bagian utama pembelajaran dan hal ini dapat meningkatkan rasa percaya diri siswa sehingga implikasi dalam pembelajaran sangat terasa: kegiatan berjalan partisipatif, kolaboratif, dan interaktif.

Dalam kaitan dengan mata pelajaran IPA, pemanfaatan media sudah seharusnya dijalankan. Pertama, struktur dan konten IPA sarat dengan konsep-konsep dan prinsip-prinsip abstrak, sehingga media mampu mengkonkretkan abstraksi-abstraksi itu sesuai kapasitas kognitif anak-anak SD yang masih bersifat operasional-konkret; Kedua, dengan melihat kapasitas kognitif anak SD dan bahwa fenomena alam adalah platform IPA SD, maka materi-materi IPA seharusnya bersifat sederhana dan praktis, yang hanya dapat dinyatakan jika dibantu dengan media. Dalam hal ini, Gagne dan Briggs (Asyhari \& Silvia, 2016:3) menekankan pentingnya media pembelajaran sebagai alat untuk merangsang proses belajar.

Media dalam pembelajaran selalu dihubunghubungkan dengan intervensi teknologi, sistem simbol, dan kemampuan pemrosesannya. Sesuatu disebut sebagai media pembelajaran jika ciri yang paling jelasnya adalah teknologinya, dalam hal ini aspek mekanis dan elektronik yang menentukan fungsinya. Media yang sangat akrab dipakai para guru sekarang ini adalah media presentasi. Media ini disusun dengan menggunakan program teknologi komputer untuk menyampaikan pesan / informasi ke dalam bentuk teks, gambar, animasi, dan video yang digabungkan menjadi satu unit dan disajikan dengan menggunakan proyektor (Sulasteri, dkk., 2018). Apabila suatu media yang menstransfer pesan atau informasi memiliki tujuan instruksional maka media itu disebut "media pembelajaran" (Arsyad, dalam Panjaitan, 2017).

Secara faktual, pemanfaatan media dalam dapat meningkatkan proses belajar siswa. Jika proses belajar baik, maka hasil belajar pasti baik. Pada proses itu, media adalah alat untuk melakukan eksperimen. Capp (2009) mengatakan bahwa dengan media, "Kita mengetahui kebenaran suatu konsep sebagai standar untuk mengacu pada keterampilan IPA, konsepkonsep, prediksi, keandalan variabel pengklasifikasian, dan sebagainya." Media pembelajaran IPA dapat digunakan dalam aktivitas praktikum dan berbagai pendekatan atau metode mengajar.

Adapun tujuan media IPA adalah membantu siswa dalam mengungkapkan fenomena alam dan menanamkan konsep dengan perlakuan (treatment). Media IPA yang digunakan dapat berupa benda yang sesungguhnya dan dapat pula berbentuk benda tiruan. Media dapat diperoleh atau dibuat dari barang-barang bekas, dari objek langsung yang kontekstual, dari bahan yang mudah dijangkau dan yang ada di sekitar lingkungan sekolah atau siswa. Pemakaian media pembelajaran dalam proses pembelajaran dapat meningkatkan pemahaman konsep dan kreativitas, sehingga siswa tertarik untuk memperhatikan penjelasan guru dan membantu siswa menerima informasi dengan semua indra (Kurniawan, 2013:8). Artinya, media yang dimanfaatkan dapat memperjelas informasi atau pesan pembelajaran, memberi tekanan pada bagian-bagian yang penting, memberi variasi dalam pengajaran, memperjelas struktur pengajaran, dan memotivasi belajar siswa.

Salah satu media pembelajaran IPA yang digunakan dalam prsoes pembelajaran adalah kit IPA. Kit IPA seringkali diabaikan dalam penggunaannya karena guru-guru belum profesional menggunakannya. Padahal hasil penelitian Sisilia dan Siregar (2017:69) menunjukkan bahwa penggunaan kit IPA dalam proses pembelajaran dapat meningkarkan motivasi dan hasil belajar IPA siswa.

Penggunaan media IPA mempunyai fungsi yang sangat penting untuk menjelaskan serta menanamkan konsep yang sulit dipahami siswa. Ada enam fungsi pokok dari media pembelajarandalam proses belajar mengajar yang dikemukakan Sudjana (2002) yaitu: (1) alat bantu untuk mewujudkan situasi belajar mengajar yang efektif, (2) merupakan bagian yang integral dari keseluruhan situasi mengajar, (3) bersifat integral dengan tujuan dan isi pelajaran, (4) bukan semata-mata alat hiburan atau pelengkap, (5) lebih dimaksudkan untuk mempercepat proses pembelajaran dan membantu siswa dalam menangkap pengertian yang diberikan guru,dan (7) diutamakan untuk mempertinggi mutu belajar mengajar. Dari fungsinya media IPA sangat menunjang dan mendukung hakikat IPA sebagai proses. maka peranan media IPA berkaitan dengan pendekatan keterampilan proses antara lain: (1) dapat mengaktifkan komunikasi dan interaksi antara guru dan siswa dan antara siwa dan sesamanya, (2) dapat merangsang pikiran, perasaan, perhatian dan kemauan untuk memperoleh pembelajaran yang lebih bermakna bagi siswa, (3) dapat membangkitkan keinginan dan minat relajar 
siswa, sehingga perhatian siswa terpusat pada materi pelajaran, (4) meletakkan dasar-dasar yang peting agar pelajaran lebih lama diingat siswa, dan (5) memberikan pengalaman nyata untuk membentuk kegiatan mandiri siswa (Panjaitan, 2017:155).

Dengan demikian, media IPA membantu siswa untuk mencari tahu tentang alam secara sistematis, sehingga IPA bukan hanya sekadar penguasaan pengetahuan berupa fakta-fakta, konsep-konsep atau prinsip-prinsip saja, tetapi juga proses penemuan (Kemendikbud, 2013). IPA bukan hanya mengumpulkan hukum-hukum, tidak seperti katalog yang terlepas dari realitas konkret, tetapi merupakan kreasi pikiran manusia dengan gagasan-gagasan penemuan bebas beserta konsep-konsepnya. Teoriteori IPA mencoba untuk menggambarkan kenyataan dan menentukan hubungannya dengan fakta-fakta yang ada di bumi.

Hal-hal di atas sebetulnya rujukan, mimpi dan harapan untuk membuat pembelajaran lebih menarik. Namun, upaya menciptakan situasi kelas yang bersifat dinamis tentu harus ditopang oleh kompetensi dan kreativitas guru dalam memanfaatkan media-media IPA. Saat ini, ketersediaan media di sekolah secara umum sudah cukup memadai. Bantuan pemerintah dalam penyelenggaraan pendidikan di sekolah dapat menolong guru dalam pengajaran, tetapi belum maksimal digunakan. Hal ini merujuk pada hasil penelitian Amran dan Muslimin (2017:69) bahwa guru belum maksimal dalam merancang rencana pembelajaran yang berbasis kit IPA. Guru harus meningkatkan kompetensi dalam menggunakan kit IPA di SD. Pada pelajaran IPA, ada banyak media yang dapat dipakai, entah media auditorial, visual, maupun audivisual. Bahkan sekolah-sekolah yang maju telah memiliki laboratorium IPA.

Hasil pengamatan terhadap sekolah-sekolah dasar di Kecamatan Langke Rembong, Kabupaten Manggarai, memperlihatkan ketersediaan media pembelajaran pada mata pelajaran IPA yang sudah cukup baik, terutama KIT IPA. Sekolah-sekolah memiliki pajangan media di banyak ruangan. Namun, media-media yang tersedia tidak dimanfaatkan secara maksimal. Guru-guru enggan menggunakan media yang ada dan lebih suka mengajar secara tradisional, dalam arti materi yang diketahui guru, lalu dijelaskan kepada siswa, dan tugas siswa adalah mencatat, mengingat, dan menuangkan kembali ingatannya saat ujian berlangsung. Kalaupun guru-guru hendak melakukan variasi pembelajaran, yang mereka lakukan adalah memanfaatkan media kontekstual. Misalnya, dalam menjelaskan materi fotosintesis, guru langsung mengambil daun yang ada di sekitar sekolah untuk diperlihatkan kepada siswa tanpa menjelaskan secara detail seperti apa fotosintesis itu sendiri. Pola seperti ini umumnya terjadi di sekolah-sekolah di Kecamatan
Langke Rembong. Untuk mengkali lebih dalam situasi pembelajaran di sekolah-sekolah tersebut, penelitian ini dilakukan dengan dua pertanyaan utama sebagai penuntun: (1) seperti apa ketersediaan media-media pembelajaran IPA di SDK se-Kecamatan Langke Rembong? (2) bagaimana kemanfaatan media-media pembelajaran IPA di sekolah-sekolah tersebut?

\section{Metode}

Penelitian ini bertujuan untuk menggambarkan keadaan ketersediaan dan pemanfaatan media pembelajaran IPA kelas VI di sekolah dasar swasta Katolik di Kecamatan Langke Rembong, Kabupaten Manggarai, NTT, sebagaimana adanya. Berdasarkan tujuan ini, maka penelitian menggunakan metode penelitian kuantitatif non eksprimen jenis deskriptif. Peneliti melakukan survei dan menyebarkan angket ke subjek penelitian dan memantau ketersediaan dan pemanfaatan media pembelajaran IPA. Populasi penelitian ini diambil dari seluruh guru kelas VI di seluruh SDK se-Kecamatan Langke Rembong yang mengajar mata pelajaran IPA dengan jumlah 46 orang. Sampel yang digunakan bersifat purposive.

Teknik pengumpulan data yang digunakan adalah: wawancara dan angket. Selanjutnya, instrumen atau alat-alat pengumpulan data dianalisis. Wawancara dilakukan secara mendalam (in-depth interview) antara tim peneliti dengan guru IPA kelas VI, sehingga panduan wawancara bertujuan untuk memperoleh informasi tentang ketersediaan dan pemanfaatan media IPA. Kuesioner/angket yang digunakan berupa angket terstruktur dengan pertanyaan tertutup yang diberikan kepada seluruh guru IPA kelas VI. Alat-alat dokumentasi juga digunakan untuk dijadikan bukti bahwa sekolah-sekolah bersangkutan memiliki atau tidak memiliki media pembelajaran IPA. Analisis instrumen data menggunakan RASCH Model dan dideskripsikan dengan menguraikan hasil penelitian.

\section{Hasil dan Pembahasan}

Data hasil penelitian diperoleh dari hasil lembar check list, penyebaran angket/kuesioner kepada guru IPA kelas VI, hasil dokumentasi terhadap media pembelajaran IPA, dan wawancara untuk menunjang dalam pemerolehan informasi. Dalam penelitian ini data dioleh secara deskriptif, yaitu hasil penelitian diuraikan dari apa yang tim peneliti lihat dan dapatkan dalam penelitian. Hasil penelitian adalah sebagai berikut. 
Tabel 1. Kategori Pentingnya Media KIT IPA di SD

\begin{tabular}{llll}
\hline Indikator & \multicolumn{3}{l}{ Kategori Pernyataan } \\
\cline { 2 - 4 } & $\begin{array}{l}\text { Sangat } \\
\text { Penting }\end{array}$ & $\begin{array}{l}\text { Kadang- } \\
\text { kadang }\end{array}$ & $\begin{array}{l}\text { Tidak } \\
\text { Penting }\end{array}$ \\
\hline $\begin{array}{l}\text { Media KIT IPA relevan } \\
\text { dengan soal-soal UN }\end{array}$ & 25 & 5 & - \\
$\begin{array}{l}\text { Media KIT IPAsangat } \\
\text { membantu proses }\end{array}$ & 30 & - & - \\
$\begin{array}{l}\text { pembelajaran } \\
\text { Media KIT IPA semua } \\
\text { dikaitkan dengan }\end{array}$ & 12 & 14 & 4 \\
$\begin{array}{l}\text { materi IPA SD } \\
\text { Kreatif membuat media } \\
\text { lain yang kontekstual }\end{array}$ & 9 & 12 & \\
Persentase (\%) & 63,3 & 25,83 & 10,83 \\
\hline
\end{tabular}

Berdasarkan pada tabel 1 di atas, terdapat 63,3\% menyatakan bahwa KIT IPA sangat penting dalam pembelajaran IPA dan relevan dengan UN di SD, sebanyak 25,83\% menyatakan kadang-kadang KIT IPA dibutuhkan dalam pembelajaran dan relevansinya Tabel 2. Hasil Wawancara Ketersediaan Media Pembelajaran IPA

\begin{tabular}{lllcccc}
\hline Nama Sekolah & \multicolumn{7}{l}{ Ketersediaan } & \multicolumn{5}{l}{} \\
\cline { 2 - 7 } & KIT IPA & Torso & LKS & Kit Gambar & Kreasi Siswa & Lab \\
\hline SDK Ruteng I & $\sqrt{ }$ & $\sqrt{ }$ & $\sqrt{ }$ & $\sqrt{ }$ & $\sqrt{ }$ & - \\
SDK Ruteng II & $\sqrt{ }$ & $\sqrt{ }$ & $\sqrt{ }$ & $\sqrt{ }$ & - & - \\
SDK Ruteng III & $\sqrt{ }$ & $\sqrt{ }$ & $\sqrt{ }$ & $\sqrt{ }$ & $\sqrt{ }$ & - \\
SDK Ruteng IV & $\sqrt{ }$ & $\sqrt{ }$ & $\sqrt{ }$ & $\sqrt{ }$ & $\sqrt{ }$ & - \\
SDK Ruteng V & $\sqrt{ }$ & $\sqrt{ }$ & $\sqrt{ }$ & $\sqrt{ }$ & $\sqrt{ }$ & - \\
SDK Ruteng VI & $\sqrt{ }$ & $\sqrt{ }$ & $\sqrt{ }$ & $\sqrt{ }$ & $\sqrt{ }$ & - \\
SDK Kumba I & $\sqrt{ }$ & $\sqrt{ }$ & $\sqrt{ }$ & $\sqrt{ }$ & $\sqrt{ }$ & - \\
SDK Kumba II & $\sqrt{ }$ & $\sqrt{ }$ & $\sqrt{ }$ & $\sqrt{ }$ & $\sqrt{ }$ & - \\
SDK Cewonikit & $\sqrt{ }$ & $\sqrt{ }$ & $\sqrt{ }$ & $\sqrt{ }$ & $\sqrt{ }$ & - \\
SDK Taga & $\sqrt{ }$ & $\sqrt{ }$ & $\sqrt{ }$ & $\sqrt{ }$ & $\sqrt{ }$ & - \\
SDK Karot & $\sqrt{ }$ & $\sqrt{ }$ & $\sqrt{ }$ & $\sqrt{ }$ & - & - \\
SDK Ka Redong & $\sqrt{ }$ & $\sqrt{ }$ & $\sqrt{ }$ & $\sqrt{ }$ & 10 & 0 \\
\hline Total & 12 & 12 & 12 & 12 & & \\
\hline
\end{tabular}

Dari hasil wawancara terhadap 30 guru di SDK se-Kecamatan Langke Rembong ditemukan bahwa sekolah-sekolah mereka memiliki media pembelajaran IPA. Hampir semua sekolah memiliki KIT IPA dan media pembelajaran lainnya. Tetapi sekolah-sekolah itu tidak memiliki laboraturium untuk praktikum IPA. Terkait penggunaan media, dari sekian media yang tersedia, guru-guru jarang memakai media dalam pembelajaran, sehingga media hanya dijadikan pajangan di ruangan guru dan perpustakaan. Sangat sedikit guru yang mengikuti pelatihan penggunaan KIT, sehingga banyak KIT IPA yang rusak karena disimpan, bukan karena dipakai. Dari hasil wawancara, penggunaan media dipersepsikan sangat membantu dalam menjelaskan konsep IPA, namun pemanfaatannya dipakai untuk membahas soal-soal UN IPA. Ada manfaat dalam penggunaan media dengan UN, dan 10,83\% menyatakan kadang-kadang tidak dibutuhkan dan tidak relevansinya dengan UN (Histogram pada Gambar 1).

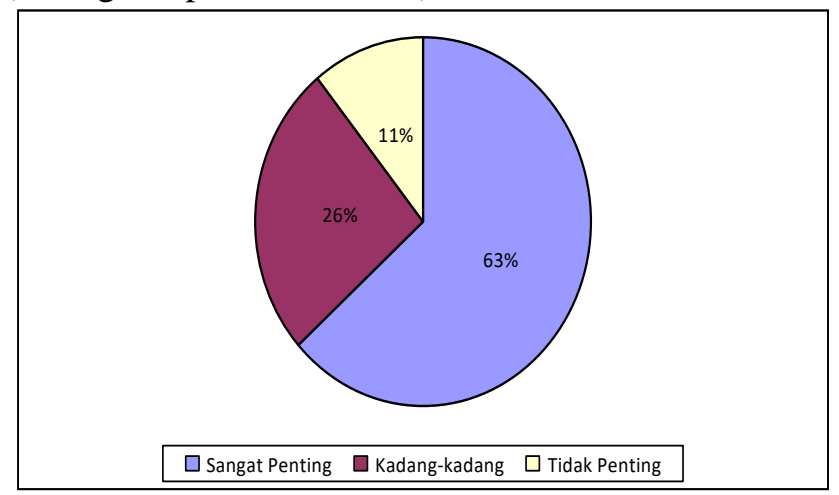

Gambar 1. Histogram Kategori Pentingnya Media KIT IPA di SD

Selanjutnya, data hasil wawancara terhadap 30 guru IPA kelas VI SDK se-Kecamatan Langke Rembong dapat dilihat pada tabel 2 di bawah ini. pembelajaran IPA dengan hasil nilai UN IPA bagi siswa (Histogram pada Gambar 2).

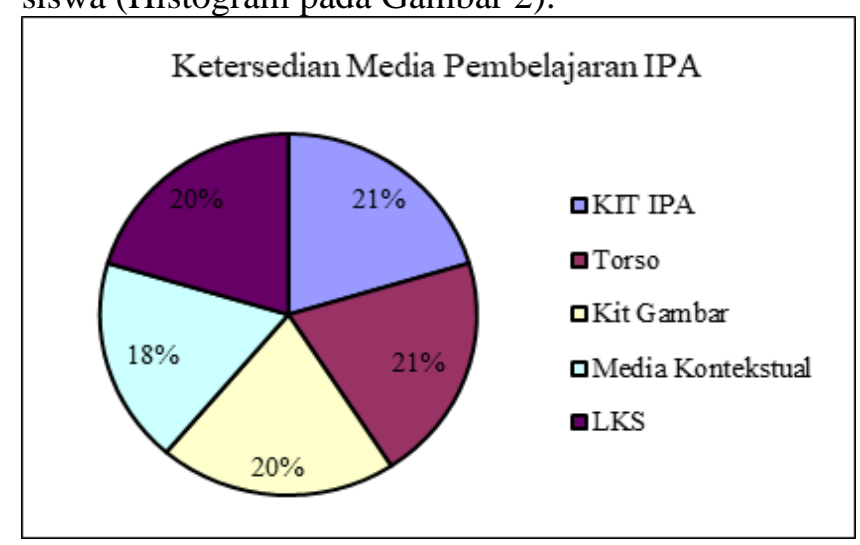

Gambar 2. Diagram Ketersediaan Media IPA di SDK seKecamatan Langke Rembong 
Dapat dilihat bahwa secara keseluruhan ketersediaan media pembelajaran IPA untuk kelas VI sudah cukup banyak, hampir setiap sekolah memiliki media pembelajaran IPA, hanya belum sepenuhnya dimanfaaatkan. Hampir semua sekolah sudah memiliki media KIT IPA. Sebelum melakukan praktikum, semua guru menyiapkan LKS. Media pembelajaran audio-visual (compact disk) hanya dimiliki 9 sekolah, sedangkan 14 sekolah tidak memilikinya. Setelah dianalisis dengan RASCH model, kecenderungan sampel penelitian menjawab kuesioner yang diberikan sangat valid. Pertanyaan-pertanyaan yang diberikan dapat memperoleh data jawaban yang sangat akurat dan valid. Hal ini secara jelas terlihat pada diagram informasi responden dalam menanggapi pertanyaan yang diberikan yang disajikan pada gambar 3 berikut ini.

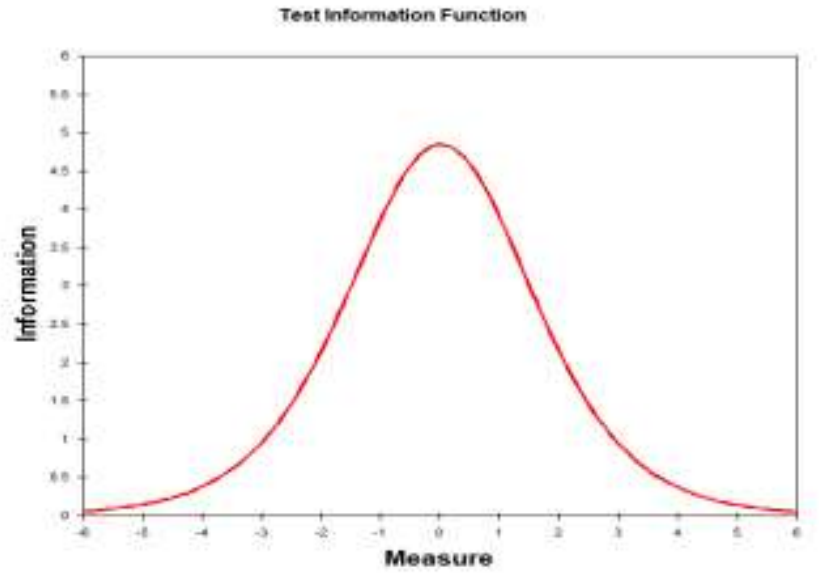

Gambar 4. Diagram Informasi Responden dalam Menjawab Pertanyaan

Berdasarkan penelusuran melalui angket dan hasil wawancara diperoleh data sebagai berikut. (1) Ketersediaan media pembelajaran IPA di semua sekolah sudah lebih dari cukup. Semua sekolah memiliki media, hanya tidak memilki laboratorium khusus untuk melaksanakan proses pembelajaran IPA secara lebih efektif. (2) Penggunaan media IPA sangat penting dilakukan dalam proses pembelajaran. Media KIT IPA dalam bentuk buku panduan praktikum sudah ada di semua sekolah, tetapi tidak digunakan dalam melaksanakan praktikum. (3) Ketersediaan dan pemanfaatan media pembelajaran berupa bahan cetak (LKS) selain buku penunjang sebagai latihan peserta didik dalam menghadapi Ujian Akhir Nasional (UAN). LKS ini sebagian besar sudah dimiliki semua sekolah di kecamatan Langke Rembong. Beberapa guru berpendapat bahwa media LKS dianggap sangat membantu proses pembelajaran. (4) Ketersediaan dan pemanfaatan media pembelajaran IPA berupa bahan cetak gambar pada dasarnya tersedia di sekolahsekolah dasar Katolik se-Kecamatan Langke Rembong. Namun, dilihat dari segi pemanfaatannya, media pembelajaran berupa gambar ini jarang dimanfaatkan, dan hanya digunakan sebagai pajangan di kelas. (5) Sementara itu, untuk media pembelajaran berupa audio visual (compact disk), ketersediannya tidak banyak. 14 sekolah tidak memiliki media ini, hal ini dikarenakan media tersebut dianggap tidak penting untuk digunakan. Sekolah yang memiliki media ini pun jarang dimanfaatkan. Beberapa guru IPA beralasan bahwa kelas VI lebih difokuskan untuk menjawab soal-soal.

\section{Kesimpulan}

Berdasarkan hasil penelitian di atas dapat disimpulkan bahwa: pertama, ketersediaan media pembelajaran IPA Kelas VI di Sekolah Dasar Katolik Kecamatan Langke Rembong pada umumnya sudah memadai untuk terlaksananya kegiatan pembelajaran, tetapi dari sekian banyak media yang ada banyak yang rusak dan tidak memungkinkan untuk digunakan dalam pembelajaran. Kedua, dari sisi pemanfaatannya, sebagian besar media pembelajaran belum dimanfaatkan secara maksimal. Ada beberapa alasan, di antaranya, kondisi media banyak yang rusak sehingga tidak memungkinkan untuk dimanfaatkan. Pembelajaran di kelas tidak begitu efektif karena peserta didik juga hanya difokuskan pada latihan soalsoal untuk persiapan mengikuti Ujian Akhir Nasional (UAN).

\section{Ucapan Terima Kasih}

Terima kasih kepada kampus Unika Santu Paulus Ruteng, khususnya Program Studi PGSD, yang memberikan kesempatan dan lingkungan akademis kepada tim peneliti untuk melaksanakan penelitian ini. Terima kasih kepada sekolah-sekolah di Kecamatan Langke Rembong, Kota Ruteng, atas kesediaan untuk memberikan informasi yang berguna bagi para pembaca.

\section{Daftar Pustaka}

Amran, M. \& Muslimin. (2017). Peningkatan Hasil Belajar dengan Menggunakan Media KIT IPA di SD Negeri Mapala Makasar. Jurnal Office, $3(1)$.

Asyhari, A. \& Silvia, H. (2016). Pengembangan Media Pembelajaran Berupa Buletin dalam bentuk Buku Saku untuk Pembelajaran IPA Terpadu. Jurnal Ilmiah Pendidikan Fisika Al-BiRuNi, 5 (1). 
Capp, R. (2009). Process Skills Standardized Tests. Jurnal. Diambil dari http://www.ProQuest.Com/pqdweb.

Kurniawan. (2013). "Metode Inkuiri Terbimbing dalam Pembutan Media Pembelajaran Biologi untuk Meningkatkan Pemahaman Konsep dan Kreativitas Siswa SMP. Jurnal Pendidikan IPA Indonesia (JPII), 2 (1).pp. 8-11

Martin, Ralph, Sexton, C., Franklin, T. \& Gerlovich, J. (2005). Teaching science for all children : Inquiry methods for constructing understanding. Boston: Pearson education inc.

Naz, A. A. \& Akbar R. Al. (2008). Use of Media for Effective Instruction its Importance: Some Consideration. Jurnal of Elementary Education, $18(1-2)$.

Nolan, P.P. (1999). Simple Machines Kit. Jurnal. Diambil dari http://www.ProQuest.Com/pqdweb.

Panjaitan, S. (2017). Meningkatkan Hasil Belajar IPA mMedia Gambar pada Siswa Kelas IIa SDN 78 Pekanbaru. Jurnal Primary Program Studi Pendidikan Guru Sekolah Dasar Fakultas Keguruan dan Ilmu Pendidikan Universitas Riau, 1(1).

Sari, A. P. \& Ananda S. (2018). The Development of Internet-Based Ec Media using Moddle Approach. International Journal of Active Learning (IJAL), 3(2).
Sisilia, A. \& Siregar, T. (2017). Pengaruh Penggunaan Media Kit IPA Terhadap Motivasi dan Hasil Belajar Siswa pada Materi Hantaran pAnas pda Benda Kelas VI Sekolah Dasar Negeri 03 Nabire. Jurnal Ilmu Pendidikan Indonesia, 5 (1). Sudjana, N. (2002) Dasar-dasar Proses Belajar Mengajar, Bandung: Sinar Baru Algensindo.

Sulasteri, Sri, dkk. (2018). The Effect of the Use of Learning Media Based on Presentation Media on Interest and Mathematical Learning Outcomes. MaPan: Jurnal Matematika dan Pembelajaran. 6(2). pp. (221-236)

Taufiq. (2014). Pengembangan Media Pembelajaran IPA Terpadu Berkarakter Peduli Lingkungan Tema Konservasi Berpendekatan Science Edutainment. Jurnal Pendidikan IPA Indonesia, $1(2)$.

Kemendikbud. (2013). Struktur Kerangka Kurikulum 2013. Jakarta

Suastra, I. W. (2017). Pembelajaran Sains Terkini; Mendekatkan Siswa dengan Lingkungan Alamiah Dan Sosial Budayanya. Universitas Pendidikan Ganesha, Singaraja.

Sugiyono. (2009). Metode penelitian pendidikan: pendekatan kuantitatif, kualitatif, dan $R \& D$. Bandung: Penerbit Alfabeta. 